\title{
Database Meadows and Steppes of South Ural
}

\author{
Sergey Yamalov, Albert Muldashev, Artem Bayanov, Tatyana Jirnova \& Aizek \\ Solomesch
}

\begin{abstract}
The Database Meadows and Steppes of South Ural (GIVD ID 00-RU-003) was established in 2002 at the Department of Ecology in Bashkir State University. It contains 1365 geobotanical relevés of meadows and steppe of South-Ural region and their mountain analogues studies were made during 1961-2008. It includes almost all the different types of non-forest vegetation of region. The database is used to develop syntaxonomy of Southern Urals non-forest vegetation, for nature conservation, for phytocoenological and ecologycal analysis of the syntaxa at all levels, for the comparison with syntaxa-analogues from other regions and investigation of relationships on the species and ecosystem levels. Also, this database is used as the basis for investigation of anthropogenic dynamics of vegetation South-Ural region and developing recommendations for stimulating restoration succession.
\end{abstract}

Keywords: Bashkortostan republic; meadow; steppe.

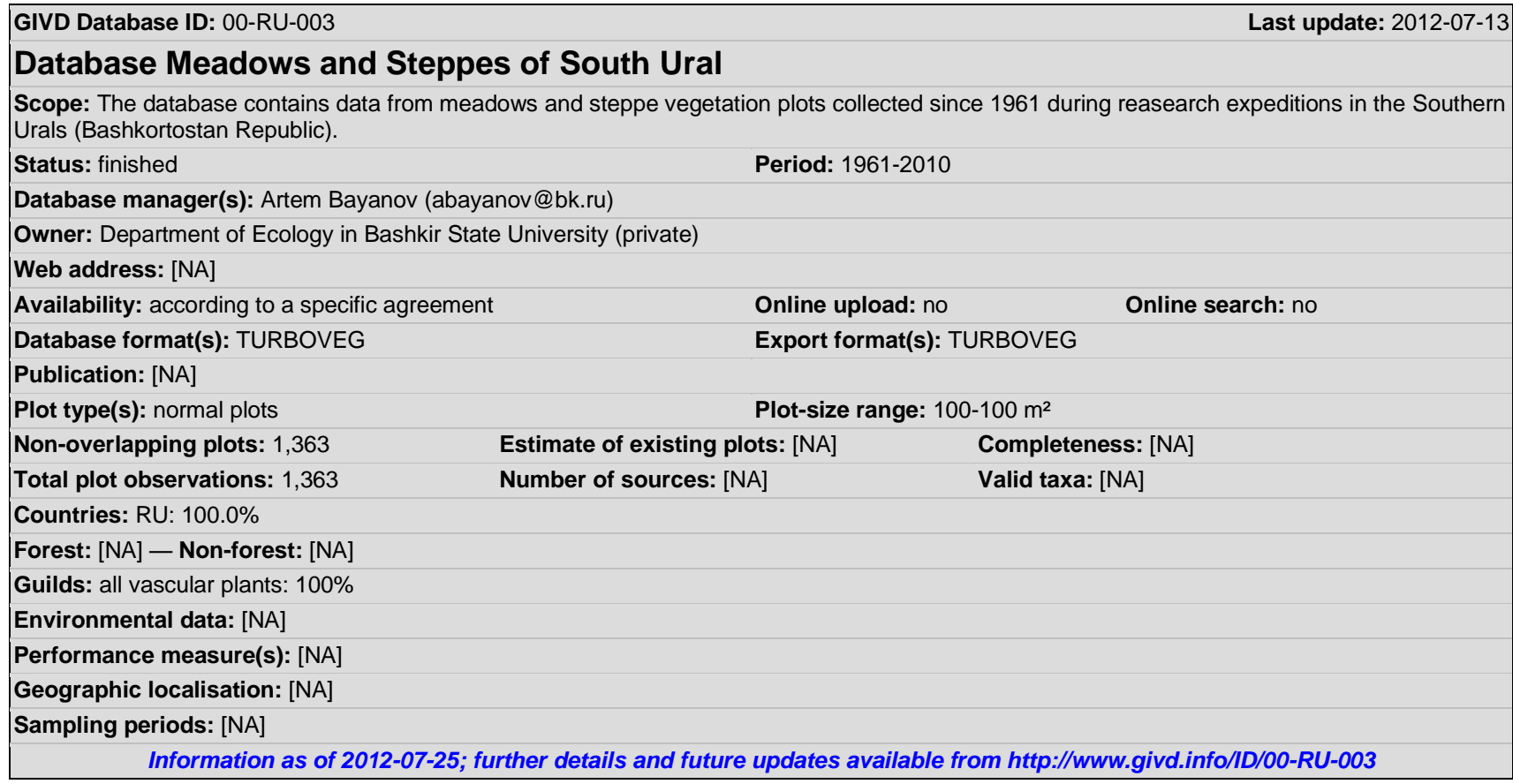

Sergey Yamalov* (geobotanika@mail.ru)

Laboratory of Wild Flora and Introduction of Herbaceous Plants, Botanical Garden-Institute Ufa Scientific Centre Russia Academy of Sciences, Mendeleev, 450080 Ufa, RUSSIA

Albert Muldashev (geobotanika@mail.ru)

Institute of Biology, Ufa Scientific Centre Russia Academy of Sciences, Prospekt Oktyabrya, 450054 Ufa, RUSSIA

Artem Bayanov (abayanov@bk.ru)

Department of Biology, Bashkir State University, Validi 32, 450074 Ufa, RUSSIA

Tatyana Jirnova (zhirnova.t@inbox.ru)

Bashkir State Reservation, 453532 Sargaja, RUSSIA

Aizek Solomesch

Department of Plant Sciences, University of California, MS1 One Shields Av., 95616 Davis, UNITED STATES

*Corresponding author 